\title{
HUBUNGAN ANTARA KOPING RELIGIUS DENGAN PENYESUAIAN DIRI PADA MAHASISWA TINGKAT AWAL DI UNIVERSITAS ISLAM SULTAN AGUNG SEMARANG
}

\author{
Dwi Sulistyani, Ratna Supradewi, dan Diany Ufieta Syafitri* \\ Fakultas Psikologi, Universitas Islam Sultan Agung, Jl. Kaligawe Raya KM. 4 Kota Semarang 50112 \\ Email : dianysyafitri@unissula.ac.id*
}

\begin{abstract}
Abstrak
Penelitian ini bertujuan untuk mengetahui hubungan antara koping religius dengan penyesuaian diri pada mahasiswa tingkat awal di Universitas Islam Sultan Agung Semarang. Variabel tergantung pada penelitian ini ialah penyesuaian diri, sedangkan variabel bebas pada penelitian ini ialah koping religius. Penelitian ini menggunakan metode kuantitatif dan analisis dilakukan pada 200 mahasiswa tingkat awal. metode pengambilan sampel yang digunakan ialah accidental sampling. Metode pengambilan data yang dilakukan ialah menggunakan dua skala, yaitu skala penyesuaian diri dan skala koping religius. Skala penyesuaian diri terdiri dari 32 aitem pernyataan yang memiliki koefisien korelasi skor aitem bergerak dari -0,003 sampai 0,599 dengan reliabilitas sebesar 0,846. Skala koping religius merupakan adaptasi dari Initial Development of the Iranian Religious Coping Scale yang dikembangkan oleh Abdulaziz Aflakseir dan Peter G. Coleman terdiri dari 18 aitem pernyataan yang memiliki koefisien korelasi skor aitem bergerak dari -0,294 sampai 0,624 dengan reliabilitas sebesar 0,737 . Uji hipotesis dalam penelitian ini menggunakan teknik analisis Product Moment. Hasil dari uji hipotesis menunjukkan terdapat hubungan positif yang signifikan antara penyesuaian diri dengan koping religius pada mahasiswa tingkat awal di Universitas Islam Sultan Agung Semarang, yaitu diketahui $r_{\mathrm{xy}}=0,483$ dengan taraf signifikansi sebesar $0,000(p<0,05)$.
\end{abstract}

Kata kunci : Penyesuain Diri, Koping Religius.

Abstract
This study aims to determine the relationship between religious coping with self-adjustment in early-level students at Sultan Agung Islamic University Semarang. The dependent variable in this study is self-adjustment, while the independent variable in this study is religious coping. This study uses quantitative methods and analysis is carried out on 200 early-level students. The sampling method used is accidental sampling. The method of data collection is using two scales, namely the adjustment scale and religious coping scale. The adjustment scale consists of 32 statement items that have a correlation coefficient item item moving from -0.003 to 0.599 with a reliability of 0.846 . The religious coping scale is an adaptation of the Initial Development of the Iranian Religious Coping Scale developed by Abdulaziz Aflakseir and Peter G. Coleman consisting of 18 statement items that have a correlation score of the item score moving from -0.294 to 0.624 with a reliability of 0.737 . Hypothesis in this study uses Product Moment analysis techniques. The results of the hypothesis test indicate that there is a significant positive relationship between religious coping with early students at Sultan Agung Semarang Islamic University, which is known to be $r x y=0.483$ with a significance level of $0.000(p<0.05)$.

Keywords: Self Adjustment, Religious Coping.

\section{Pendahuluan}

\subsection{Latar Belakang}

Jumlah mahasiswa baru di setiap tahunnya semakin bertambah. Data yang didapat dari Badan Pusat Statistik pada periode tahun ajaran 2013/2014 tercatat 613.665 mahasiswa yang terbagi dalam 341.315 mahasiswa pada perguruan tinggi negeri dan 272.350 mahasiswa pada perguruan tinggi swasta. Sedangkan pada periode tahun ajaran 2014/2015 terjadi peningkatan jumlah mahasiswa yaitu sebanyak 89.181 mahasiswa yang terbagi pada 391.644 mahasiswa pada perguruan tinggi negeri dan 22 E-ISSN 2656-4173

P-ISSN 1907-8455 
297.537 mahasiswa pada perguruan tinggi swasta. ("Statistik Pendidikan Tinggi 2014/2015," 2014). Hasil penelitian dari Davis (2011), mengemukakan bahwa masalah penyesuaian diri paling banyak terjadi pada mahasiswa tahun pertama, diantaranya ialah mencemaskan ujian, kurang mengetahui bagaimana cara belajar, kurang mampu berkonsentrasi, kesulitan berbicara didepan kelas, kurangnya waktu untuk belajar, kurang mampu dalam membuat karya tulis, kesulitan untuk mengingat, serta takut gagal dalam perkuliahan.

Menurut Hurlock (1980) masa remaja adalah masa yang mudah untuk goyah bagi seorang remaja, dimana individu masih berupaya untuk mencari tahu siapa dirinya tanpa adanya pemikiran yang matang. Dengan hal ini, individu dituntut untuk mampu menyesuaikan diri baik pada dirinya maupun lingkungannya. Selain itu, diharapan individu dapat berinteraksi dengan baik pada diri dan lingkungan. Pada tahap memasuki masa dewasa awal, mahasiswa akan mengalami beberapa perubahan yang membutuhkan penyesuaian diri, hal ini ditandai dengan beberapa kegiatan seperti memasuki dunia perkuliahan, mulai bekerja, meninggalkan rumah, menikah dan memiliki anak, dimana kegiatan ini terjadi dalam waktu yang bervariasi (Astrini, 2011).

Menurut Willis (2005), penyesuaian diri merupakan bekal utama individu untuk dapat terjun dalam kehidupan masyarakat luas, penyesuaian diri juga sebagai syarat terbentuknya kesehatan mental dan kesehatan jiwa seorang individu. Beberapa individu yang kurang dapat untuk menggapai kebahagiaan disebabkan karena ketidak mampuan untuk menyesuaikan diri, cenderung menjadi individu yang tertutup, suka menyendiri, dan kurang percaya diri. Utomo (2008) mengungkapkan bahwa permasalahan yang banyak dialami oleh mahasiswa tingkat awal ialah kesulitan dalam mengikuti proses perkuliahan, terjadinya perubahan lingkungan, adanya tuntutan secara akademik, serta faktor jauh dari orang tua dan homesick.

McMahon dan Biggs (2012) melakukan penelitian yang memperlihatkan bahwa individu dengan tingkat spiritual atau religiusitas yang tinggi serta menggunakan koping religiusdalam kehidupannya, maka individu akan cenderung lebih tenang dan tidak mudah cemas dalam menghadapi masalahnya, kekuatan spiritual inilah yang dapat membangkitkan rasa kepercayaan diri dan optimisme individu. Menurut Pargament, Feuille, dan Burdzy (2011) koping religius merupakan usaha yang individu lakukan untuk mengatasi tekanan yang dialami dengan cara yang baik, Karekla dan Constantinou (2010) juga mengungkapkan bahwa koping religius melibatkan proses kognitif serta perilaku yang muncul ketika menghadapi stressor berasal dari agama yang dipercayai oleh individu tersebut. Individu mempersepsikan bahwa segala sesuatunya telah ditentukan oleh Tuhan, dan perilaku apa yang individu lakukakan adalah apa yang telah agamanya ajarkan, seperti berdoa, dan beribadah. Peralaiko (2013) mengatakan bahwa koping religius merupakan proses yang individu lakukan untuk mengatur serta merubah respon secara emosional dan perilaku dengan mengunakan sumber daya rohani yang dimiliki baik secara pribadi maupun sosial berdasarkan apa yang agamanya ajarkan.

Beberapa penelitian lainnya (Utami, 2012) mengatakan bahwa pentingnya kontribusi dalam sebuah komitmen religius serta dorongan secara spiritual terhadap penyesuaian individu dalam menghadapi stres. Berdasarkan penelitian yang dilakukan oleh Ano dan Vasconcelles (2005), terdapat hubungan antara koping religius dan penyesuaian diri terhadap stres. Hasil penelitian yang telah dilakukan oleh Armiyati, Rahayu, dan Aisah (2015) mengatakan bahwa ketika ODHA tidak mengalami kecemasan dan bersikap lebih tenang, maka mereka akan lebih mudah untuk beradaptasi atau menyesuaikan diri, hal yang sama juga diakui oleh temuan dari Muslimah, Alfiana, Aliyah, dan Siti (2013) dengan subjek pasien 
penderita HIV/AIDS mengemukakan hasil bahwa tingkat kecemasan memiliki hubungan yang signifikan terhadap penyesuaian diri, sehingga strategi koping penguatan diri dan strategi koping religius cenderung akan meningkat penyesuaian diri dari ODHA. Penelitian yang dilakukan oleh Armiyati, Wuryanto, dan Sukraeny (2016), bahwa strategi koping religius akan mampu meningkatkan penyesuaian diri dari pasien hemodialis

Mosher dan Handal (1997), mengatakan bahwa rendahnya tingkat religiusitas memiliki korelasi terhadap tingkat stres yang tinggi dan tingkat penyesuaian diri yang rendah pada remaja, sehingga individu yang memiliki hubungan yang langsung dengan Tuhan, cenderung tidak mudah untuk terpengaruh oleh stresor. Penelitian yang dilakukan oleh Armiyati, Wuryanto, dan Sukraeny (2016), bahwa strategi koping religius akan mampu meningkatkan penyesuaian diri dari pasien hemodialis.

\subsection{Tinjauan Literatur \\ Penyesuaian Diri}

Haber dan Runyon (1984) menjelaskan, penyesuaian diri ialah suatu proses yang individu akan lakukan dalam menghadapi kondisi lingkungan yang akan terus berubah selama kehidupan individu, dengan demikian tujuan dalam hidup individu juga akan terus berubah seiring dengan terjadinya perubahan keadaan lingkungan. Berdasarkan konsep ini, kemampuan individu dalam menghadapi kondisi lingkungan yang akan terus berubah, merupakan sebuah ukuran bagi individu apakah penyesuaian diri yang dilakukan oleh individu tersebut efektif atau tidak. Vembriarto (1993), mengatakan bahwa penyesuaian diri ialah reaksi individu ketika dihadapkan pada suatu tuntutan tertentu, dimana tuntutan tersebut dapat berupa tuntutan secara eksternal dan internal.

Fatimah (2010) mengemukakan penyesuaian diri dapat dipengaruhi oleh beberapa faktor, diantaranya ialah faktor fisiologis atau kesehatan jasmani, faktor psikologis yang merupakan hasil pembelajaran, pengalaman, keinginan, aktualisasi diri dsb, serta faktor perkembangan dan kematangan individu yang berbeda-beda.

Haber dan Runyon (1984) menyebutkan aspek-aspek penyesuaian diantaranya ialah:

a. Persepsi yang akurat terhadap realitas yaitu individu juga mampu mengenali konsekuensi dari tindakan yang dilakukan untuk dapat menuntut pada tingkah laku yang lebih baik.

b. Kemampuan menghadapi stres dan kecemasan yaitu individu yang dapat menangani stres dan kecemasan merupakan ciri individu yang mampu menangani masalah dalam hidupnya dan dapat mengakui segala kekalahan yang ditemui.

c. Gambaran diri yang positif yaitu individu harus dapat mengetahui dan mengakui kekurangan juga kelebihan yang dimiliki, sehingga individu mampu untuk memahami dirinya dan mampu untuk mengembangkan potensi yang dimiliki secara keseluruhan.

d. Kemampuan mengekspresikan perasaan yaitu dimana kontrol dalam menghadapi masalah akan membuat individu dapat mengungkapkan perasaan secara tepat.

e. Hubungan interpersonal yang baik yaitu individu yang mampu untuk melakukan peyesuaian diri dengan baik akan dapat menciptakan sebuah hubungan simbiosis mutualisme, yaitu hubungan yang saling menguntungkan antara satu dan lainnya.

Berdasarkan dari beberapa penjelasan diatas, maka dapat peneliti simpulkan bahwa penyesuaian diri ialah perilaku yang individu lakukan dalam mengatasi dan melalui sebuah konflik, berubahnya kondisi lingkungan, tuntutan (eksternal dan internal), dan fustasi. Penyesuian diri juga berupa 
Hubungan Antara Koping Religius dengan Penyesuaian Diri pada Mahasiswa Tingkat Awal di Universitas Islam Sultan Agung Semarang Proyeksi, Vol. 14 (2) 2019, 22-31

bagaimana individu bergaul dengan orang lain disekitarnya secara baik dan tepat. Mahasiswa dipaksa untuk mampu untuk menyesuaikan diri pada bidang akademik, sosial, emosional dan keterikatan pada intuisi dimana hal ini dapat menyebabkan stres pada mahasiswa.

\section{Koping Religius}

Pargament (1997) mengatakan bahwa koping religius cenderung digunakan ketika individu menginginkan sesuatu yang tidak dapat diperoleh dari orang lain, dan individu sadar bahwa dirinya tidak mampu untuk menghadapi kenyataan tersebut, indiviu mengalihkan kelemaan yang dimiliki kepada kekuatan yang digunakan untuk menghadapi kenyataan. Karekla dan Canstantinou (2010) menyatakan bahwa koping religius merupakan proses yang melibatkan kognitif dan perilaku yang hadir merupakan perilaku yang telah agamanya ajarkan ketika menghadapi situasi yang menekan. Yasinta (2017) mengungkapkan bahwa koping religius ialah reaksi individu ketika dihadapkan pada situasi yang menekan atau stres, dimana individu menggunakan cara-cara yang telah Tuhannya ajarkan.

Ward (2010) mengungkapkan bahwa koping religius muncul pada saat individu berada pada kondisi kritis atau situasi genting, seperti kecelakaan, kematian orang terdekat, terkena penyakit kritis, dan kegagalan dalam meraih suatu keinginan yang dapat menimbulkan stres. Menurut Ward semakin besar stres yang dialami oleh individu maka semakin besar pula tingkat religius yang digunakan untuk menanganinya. Angganantyo (2014) mengatakan bahwa koping religius ialah suatu cara koping yang menggunakan bagian keagamaan yang akan memberikan dampak yang signifikan dalam kehidupan yang umumnya ditemui pada beragam situasi.

Aflakseir dan Coleman (2010) mengatakan bahwa dalam agama Islam terdapat kepercayaan dan praktik keagamaan yang digunakan sebagai sumber kekuatan dalam menghadapi kesulitan hidup, dimana Islam mengajarkan individu untuk bersabar, berdo'a dan percaya kepada Tuhan pada saat membutuhkan bimbingan.

Berdasarkan penjelasan diatas, maka dapat ditarik kesimpulkan bahwa koping religius ialah cara yang individu gunakan baik secara kognitif maupun perilaku, ketika individu dihadapkan pada kondisi genting atau kritis yang individu sendiri tidak mampu untuk mengatasinya. Sehingga individu memilih menggunakan cara-cara yang telah agamanya ajaran.

Aflakseir dan Coleman (2010) menyebutkan bahwa terdapat beberapa aspek koping religius yang relevan dengan konsep Islam, yaitu : a. Religious practice (Praktek agama) merupakan gambaran perilaku individu yang berfokus kepada pelaksanaan serta menjalankan tuntunan agamanya, seperti shalat dan berdo'a. b. Negative feeling toward God (Perasaan negatif pada Tuhan) merupakan penggambaran yang negatif dari individu terhadap Tuhan akan masalah yang dialami, seperti individu merasa bahwa Tuhan telah melupakan dirinya. c. Religious benevolent reappraisal (Penilaian penuh kebijakan) yaitu memperhitungkan kembali sebuah permasalahan yang individu alami melalui agama selaku sesuatu yang bersifat kebaikan dan berpotensi menguntungkan, individu dapat mengambil pelajaran dari masalah yang ada. d. Passive religious coping strategy (Koping religius pasif) menggambarkan perilaku koping religius secara pasif, individu cenderung untuk menunggu Tuhan mengendalikan situasi yang ada, dimana individu hanya mengharapkan Tuhan untuk memecahkan permasalahannya. e. Active religious coping strategy (Koping religius aktif) menggambarkan perilaku koping religius secara aktif, dimana individu cenderung melakukan hal yang ia bisa semampunya dan menyerahkan sisanya pada Tuhan. 


\section{Metode Penelitian}

Penelitian ini menggunakan metode penelitian kuantitatif. Teknik pengambilan sampel yang digunakan adalah teknik accidental sampling. Populasi yang digunakan dalam penelitian ini yaitu mahasiswa tingkat awal angkatan 2017/2018 di Universitas Islam Sultan Agung Semarang. Sampel yang digunakan ialah sebanyak 200 mahasiswa.

Tabel 1. Jumlah subjek tiap fakultas 1

\begin{tabular}{clc}
\hline No & \multicolumn{1}{c}{ Fakultas } & Jumlah Subjek \\
\hline 1 & Fakultas Agama Islam & 39 \\
2 & Fakultas Kedokteran Gigi & 46 \\
3 & Fakultas Teknik Industri & 32 \\
4 & Fakultas Keperawatan & 27 \\
5 & Fakultas Kedokteran & 56 \\
\hline & Total & $\mathbf{2 0 0}$ \\
\hline
\end{tabular}

\section{Variabel dan Instrumen Penelitian}

Pada penelitian ini terdapat dua variabel yakni variabel bebas $(X)$ dan variabel terikat $(Y)$. Adapun yang menjadi variabel bebas $(X)$ yaitu koping religius dan variabel terikat $(Y)$ adalah penyesuaian diri.

Definisi operasional dari penyesuaian diri ialah perilaku yang individu lakukan dalam menghadapi kondisi lingkungan yang terus berubah. Penyesuaian diri pada mahasiswa ialah mahasiswa diharapkan dapat berinteraksi secara tepat dengan lingkungannya dan mahasiswa diharapkan dapat mengatasi berbagai tuntutan yang ada pada bidang akademik, sosial, emosional dan ketertarikan pada intuisi. Sedangkan definisi operasional dari koping religius ialah cara yang individu gunakan ketika dihadapkan pada berbagai tuntutan baik secara kognitif maupun perilaku, dimana individu mengatasinya dengan melakukan cara-cara berdasarkan ajaran agamanya.

Persiapan pada penelitian ini diawali dengan persiapan perizinan, kemudian persiapan alat ukur atau skala, pelaksanaan uji coba alat ukur, pengerjaan uji daya beda item, serta uji estimasi reliabilitas alat ukur. Persiapan tersebut dilakukan guna meminimalisir tingkat kesalahan saat dilakukannya penelitian.

\section{Metode Penelitian}

Metode pengumpulan data dalam penelitian ini menggunakan skala psikologi. Skala yang digunkan dalam penelitian ini terdiri dari dua skala yaitu skala penyesuaian diri dan skala koping religius. Skala penyesuaian diri akan diukur dengan skala penyesuaian diri yang disusun berdasarkan aspek dari Haber dan Runyon yaitu: persepsi yang akurat terhadap realitas, kemampuan menghadapi stres dan kecemasan, gambaran diri yang positif, kemampuan mengekspresikan perasaan, dan hubungan interpersonal yang baik. Skala penyesuaian diri terdiri dari 32 aitem pernyataan yang memiliki koefisien korelasi skor aitem bergerak dari -0,003 sampai 0,599 dengan reliabilitas sebesar 0,846, dan koefisien reliabilitas Alpha Cronbach sebesar 0,846. Skala koping religius merupakan adaptasi dari Initial Development of the Iranian Religious Coping Scale yang dikembangkan oleh Abdulaziz Aflakseir 
dan Peter G. Coleman, PhD yaitu religious practice (praktek agama), negative feeling toward God (perasaan negatif pada Tuhan), religious benevolent reappraisal (penilaian penuh kebijakan), passive religious coping strategy (koping religius pasif), active religious coping strategy (koping religius aktif), terdiri dari 18 aitem pernyataan yang memiliki koefisien korelasi skor aitem bergerak dari -0,294 sampai 0,624 dengan reliabilitas sebesar 0,737 dan koefisien reliabilitas Alpha Cronbach sebesar 0,737.

Uji validitas yang digunakan dalam penelitian ini menggunakan validitas isi. Perhitungan uji daya diskriminasi aitem menggunakan uji product moment. Estimasi reliabilitas menggunakan teknik alpha Cronbach dan teknik analisis data yang digunakan adalah product moment.

Tabel 2. Indeks Reliabilitas Alat Ukur Penelitian

\begin{tabular}{lcc}
\hline Alat Ukur & $\begin{array}{l}\text { Jumlah Item } \\
\text { Valid }\end{array}$ & $\begin{array}{l}\text { Indeks } \\
\text { Reliabilitas }\end{array}$ \\
\hline Koping Religius & 22 & 0,848 \\
Penyesuaian Diri & 46 & 0,879 \\
\hline
\end{tabular}

\section{Hasil Penelitian}

\section{Deskripsi Data Skor Penyesuaian Diri}

Skala penyesuaian diri terdiri dari 32 aitem dengan daya beda aitem yang tinggi dan pada setiap aitem terdapat rentang skor antara dari 1 sampai 5 . Skor terendah yang didapat oleh subjek ialah 32 (32 × 1) kemudian skor tertinggi adalah 160 (32 × 5). Rentang skor skala adalah sebesar $128(160-32)$ yang dibagi dalam lima satuan standar deviasi, sehingga diperoleh standar deviasi sebesar 21,333 ([160-32] : 6) dengan mean hipotetik sebesar 96 ([32 + 160] : 2).

Deskripsi skor pada skala penyesuaian diri didasarkan pada hasil penelitian (empirik) maka diperoleh skor minimum sebesar 80 , dan skor maksimum sebesar 150 , mean yang dimiliki sebesar 115,98 dan standar deviasi yang diperoleh sebesar 12,586. Berikut merupakan deskripsi skor skala penyesuaian diri:

Tabel 3. Deskripsi Skor Skala Penyesuaian Diri

\begin{tabular}{lcc}
\hline & Empirik & Hipotetik \\
\hline Skor Minimum & 80 & 32 \\
Skor Maksimum & 150 & 160 \\
& 115,98 & 96 \\
Mean (M) & 12,586 & 21,333 \\
\hline
\end{tabular}

\section{Deskripsi Data Skor Koping Religius}

Skala koping religius pada penelitian ini memiliki 18 aitem yang memiliki daya beda aitem yang tinggi pada setiap aitem dengan rentang skor antara dari 1 sampai 5 . Skor terendah yang didapat oleh subjek ialah $18(18 \times 1)$ skor tertinggi adalah 90 (18 x 5). Rentang skor skala adalah sebesar $72(90-18)$

\begin{tabular}{l|l} 
E-ISSN $2656-4173$ & 27 \\
P-ISSN $1907-8455$ &
\end{tabular}


yang dibagi dalam lima satuan standar deviasi, dengan demikian didapatkan standar deviasi sebesar 12 ([90 - 18] : 6) dengan mean hipotetik sebesar $54([18+90$ ] : 2).

Deskripsi skor skala koping religius berdasarkan hasil penelitian secara (empirik) didapatkan skor minimum berupa 29, skor maksimum sebanyak 90, dengan mean 75,18 dan nilai standar deviasi 9,049. Berikut merupakan deskripsi skor skala koping religius,

Tabel 4. Deskripsi Skor Skala Koping Religius

\begin{tabular}{lcc}
\hline & Empirik & Hipotetik \\
\hline Skor Minimum & 29 & 18 \\
Skor Maksimum & 90 & 90 \\
Mean (M) & 75,18 & 54 \\
Standar Deviasi & 9,049 & 12 \\
\hline
\end{tabular}

\section{Hasil Uji Korelasi}

Hasil uji korelasi antara penyesuaian diri dengan koping religius pada mahasiswa diperoleh hasil $r_{x y}$ sebesar 0,483 dengan skor tingkat signifikansi sebesar $0,000(p<0,05)$. Hasil ini menunjukkan bahwa terdapat sebuah hubungan positif yang signifikan antara penyesuaian diri dengan koping religius pada mahasiswa tingkat awal di Universitas Islam Sultan Agung Semarang. Hasil penelitian menunjukkan bahwa penelitian ini memberikan sumbangan efektif sebesar $23,3 \%$ yang dilihat berdasarkan $\mathrm{R}$ square sebesar 0,233.

Tabel 5. Hasil uji korelasi

\begin{tabular}{|c|c|c|c|}
\hline & & Penyesuaian Diri & Koping Religius \\
\hline Penyesuaian diri & $\begin{array}{l}\text { Pearson } \\
\text { Correlation } \\
\text { Sig. (2-tailed) } \\
\mathrm{N}\end{array}$ & $\begin{array}{r}1 \\
200\end{array}$ & $\begin{array}{r}.483^{* *} \\
.000 \\
200\end{array}$ \\
\hline Koping Religius & $\begin{array}{l}\text { Pearson } \\
\text { Correlation } \\
\text { Sig. (2-tailed) } \\
\mathrm{N}\end{array}$ & $\begin{array}{r}.483^{* *} \\
.000 \\
200\end{array}$ & $\begin{array}{r}1 \\
200\end{array}$ \\
\hline
\end{tabular}

\section{Pembahasan}

Penelitian yang dilakukan oleh Davis (2011) mengatakan bahwa masalah penyesuaian diri paling banyak dialami oleh mahasiswa pada tahun pertama, diantaranya adalah kecemasan dalam menghadapi ujian, kurang mampu dalam berkonsentrasi, kesulitan untuk dapat berbicara di depan, kurannya waktu untuk belajar serta ketakutan akan kegagalan dalam perkuliahan. Blyth (1983) menyatakan bahwa kemampuan penyesuaian diri sangat diperlukan pada masa transisi kehidupan, 
yang salah satunya ialah pada saat masa transisi sekolah, dimana situasi ini cenderung dapat menjadi pemicu terjadi stres yang diakibatkan oleh proses perubahan pada masa awal pendidikan.

Koping religius melibatkan proses secara kognitif dan perilaku yang muncul merupakan perilaku yang telah agamanya ajarkan ketika dihadapkan pada situasi yang menekan (Karekla \& Constantinou, 2010), seperti yang Yasinta (2017) kemukakan bahwa koping religius ialah reaksi yang muncul pada individu ketika individu dihadapkan pada situasi yang menekan atau stres, maka individu akan menggunakan cara-cara yang telah Tuhannya ajarkan. Ketika mahasiswa berhadapan dengan kondisi situasi yang baru, yang dapat mengakibatkan stres, mahasiswa akan cenderung menggunakan caracara seperti yang agamanya telah ajarkan. Maftuhan (2014) juga mengatakan penggunaan koping religius pada penyelesaian masalah juga dipengaruhi oleh tempat dimana individu tinggal. Penelitian yang dilakukan oleh Utami (2012), mengungkapkan bahwa mahasiswa akan cenderung menggunakan koping religius positif ketika menghadapi situasi yang kurang menyenangkan, mahasiswa akan memaknainya secara positif dan ikhlas dalam menerima kenyataan, dengan cara melakukan ibadah, menjauhi perbuatan maksiat, serta senantiasa mamatuhi ajaran Allah. Mahasiswa juga cendrung mendekatkan diri ke Allah, dengan memohon dukungan, meminta bantuan serta kekuatan dari Allah, dengan demikian mahasiswa dapat menahan amarahnya dam menanggulangi kesedihan yang ada. Penelitian yang dilakukan oleh Satiti, Prayitno, dan Aripin (2015) mengatakan bahwa koping religius merupakan variabel yang paling berpengaruh terhadap depresi pada mahasiswa baru.

Hasil dari penelitian oleh Muslimah dan Aliyah (2013) pada pasien penderita HIV/AIDS mengungkapkan bahwa terdapat sebuah hubungan yang signifikan antara strategi koping religius dengan penyesuaian diri. Hasil penelitian lainnya, oleh Armiyati, Wuryanto, dan Sukraeny (2016) mengungkapkan bahwa strategi koping religius akan meningkatkan penyesuaian diri pada pasien homodialisis, banyak partisipan yang menyatakan bahwa kekuatan iman dan doa memiliki efek yang positif, seperti melakukan berserah diri kepada Tuhan dan berdoa.

Penelitian ini menunjukkan hasil berupa koping religius mempunyai pengaruh terhadap penyesuaian diri pada mahasiswa. Penyesuaian diri yang dimiliki pada mahasiswa pada penelitian ini tergolong tinggi, hal ini sesuai dengan skor mean empirik penyesuaian diri yaitu sebesar 115,98 yang termasuk dalam kategori tinggi. Koping religius pada mahasiswa dalam penelitian ini tergolong sangat tinggi, dapat dilihat pada skor mean empirik yang tergolong sangat tinggi sebesar 75,18. Bagaimanapun, penelitian ini masih memiliki beberapa kekurangan diantaranya peneliti kurang melakukan uji keterbacaan skala koping religius setelah dilakukannya proses adaptasi. Selain itu skala penyesuaian diri pada penelitian ini masih bersifat umum dan kurang spesifik dalam mengungkap penyesuaian diri di lingkungan perkuliahan.

\section{Kesimpulan}

Berdasarkan dari hasil penelitian yang telah dilakukan memperlihatkan bahwa terdapat hubungan positif dan signifikan antara koping religius dengan penyesuaian diri pada mahasiswa tingkat awal di Universitas Islam Sultan Agung Semarang. Hal ini berarti bahwa semakin tinggi koping religius yang dilakukan akan semakin tinggi pula kemampuan penyesuaian diri yang dimiliki oleh subjek.

\section{DAFTAR PUSTAKA}


Dwi Sulistyani, Ratna Supradewi, dan Diany Ufieta Syafitri

Aflakseir, A., \& Coleman, P. G. (2010). Initial development of the Iranian religious coping scale. Journal of Muslim Mental Health, 6(1), 44-61. https://doi.org/http://dx.doi.org/10.381607.0006.104

Armiyati, Y., Wuryanto, E., \& Sukraeny, N. (2016). Manajemen masalah psikososiospiritual pasien chronic kidney disease ( $c k d$ ) dengan hemodialisis di kota semarang. Muhammadiyah Semarang.

Astrini. (2011). Masa orientasi dan penyesuaian diri mahasiswa baru hasil. Jurnal Humaniora, 2(1), 452-458.

Blyth, D. A., Simmons, R. G., \& Ford, S. C. (1983). The adjustment of early adolescents to school transitions. Journal of Eraly Adolescence, 3(1-2), 105-120.

Davis, L. . D. (2011). Gambaran masalah penyesuaian diri pada mahasiswa tahun pertama Universitas Indonesia. Universitas Indonesia.

Fatimah, E. (2010). Psikologi perkembangan peserta didik. Bandung: Pustaka Setia.

Haber, A., \& Runyon, R. P. (1984). Psychology of adjusment. Homewood, III : Dorsey Press.

Hurlock, E. B. (1980). Psikologi perkembangan suatu pendekatan rentang kehidupan. Jakarta: Erlangga.

Karekla, M., \& Constantinou, M. (2010). Religious coping and cancer: Proposing and acceptance and commitment therapy approach. Cogntive and Behavioral Practice, 17, 371-381.

McMahon, B. T., \& Biggs, H. C. (2012). Examining spirituality and intrinsic religious orientation as a means of coping with exam anxiety. Diunduh 13 November, 2017, dari Vulnerable Groups \& Inclusion, 3, 1-21. https://doi.org/10.3402/vgi.v3i0.14918

Mosher, J. ., \& Handal, P. J. (1997). The relationship between religion and psychological distress in adolescents. Journal of Psychology and Theology, 25, 449-457.

Pargament, K. I. (1997). The psychology of religion and coping : theory, research, practice. New York: The Guilford Press.

Statistik Pendidikan Tinggi 2014/2015. (2014). Retrieved from http://www.ristekdikti.go.id/wpcontent/uploads/2016/11/E-Book-Statistik-Pendidikan-Tinggi-2014-2015-revisi.pdf

Utami, M. S. (2012). Religiusitas, koping religius, dan kesejahteraan subjektif. Jurnal Psikologi, 39(1), $46-66$.

Utomo. (2008). Hubungan antara model-model coping stres dengan tingkat stres pada mahasiswa tahun pertama fakultas psikologi universitas islam negeri (uin) malang. UIN Malang.

Vembriarto, S. . (1993). Sosiologi pendidikan. Yogyakarta: Yayasan Pendidikan Paramita.

Ward, A. M. (2010). The relationship between religiosity and religious coping to stress reactivity and 
Hubungan Antara Koping Religius dengan Penyesuaian Diri pada Mahasiswa Tingkat Awal di Universitas Islam Sultan Agung Semarang Proyeksi, Vol. 14 (2) 2019, 22-31

psychological well-being. Georgia State University. 5 Desember, 2017, dari http://scholarworks.gsu.edu/cps_diss

Willis, S. S. (2005). Remaja dan masalahnya. Bandung: Alfabeta.

Yasinta, T. (2017). Koping religius pada individu yang mengalami konversi agama. UIN Sunan Kalijaga Yogyakarta. 